OPEN ACCESS

Edited by:

Marcello Iriti,

Università degli Studi di Milano, Italy

Reviewed by:

Palanivel Ganesan,

Konkuk University, South Korea

Karl Tsim,

Hong Kong University of Science and Technology, Hong Kong

*Correspondence:

Viduranga Y. Waisundara

viduranga@gmail.com

Specialty section:

This article was submitted to

Food Chemistry,

a section of the journal

Frontiers in Nutrition

Received: 27 May 2018 Accepted: 27 September 2018

Published: 30 October 2018

Citation:

Banjari I, Marček T, Tomić S and Waisundara VY (2018) Forestalling the

Epidemics of Parkinson's Disease

Through Plant-Based Remedies.

Front. Nutr. 5:95

doi: 10.3389/fnut.2018.00095

\section{Forestalling the Epidemics of Parkinson's Disease Through Plant-Based Remedies}

\author{
Ines Banjari ${ }^{1}$, Tihana Marček ${ }^{1}$, Svetlana Tomić ${ }^{2}$ and Viduranga Y. Waisundara ${ }^{3 *}$ \\ ${ }^{1}$ Department of Food and Nutrition Research, Faculty of Food Technology Osijek, Josip Juraj Strossmayer University of \\ Osijek, Osijek, Croatia, ${ }^{2}$ Department of Neurology, Osijek University Hospital Center, Osijek, Croatia, ${ }^{3}$ Department of Food \\ Technology, Faculty of Technology, Rajarata University of Sri Lanka, Mihintale, Sri Lanka
}

Parkinson's disease (PD) as the second leading neurodegenerative disease, imposes a heavy burden among individuals as well as economies worldwide. The main characteristics of PD is a progressive loss of dopaminergic neurons resulting in the loss of motor function, the occurrence of non-motor symptoms, and cognitive decline. Similar to many other chronic diseases, complementary and alternative therapies (CAT) are very popular for the treatment of this disease. This review evaluates six plants, three each from European and Asian traditional medicinal systems: (1) Atropa belladonna, (2) Hyoscyamus niger, (3) Lepidium meyenii, (4) Aspargus racemosus, (5) Mucuna pruriens L., and (6) Gingko biloba. Atropa belladonna, and Hyoscyamus niger in particular, are better known for their poisonous and narcotic effects than as potentially effective plants for the treatment of neurodegenerative diseases. Ginkgo biloba is one of the most widely cultured plants in Traditional Chinese Medicine with high antioxidant potential which contributes to its neuroprotective/ anti-apoptotic activity. The bioactive compounds, anti-neurodegenerative effects and other neuroprotective effects of all six plants are discussed herein.

Keywords: Asia, Europe, complementary and alternative therapies, parkinson's disease, traditional medicinal herbs

\section{INTRODUCTION}

Parkinson's disease (PD) is the second most common neurodegenerative disease globally. Currently, approximately 6 million people worldwide or around 1\% among those over 60 years of age are affected by PD (1). Recent meta-analysis revealed a rising prevalence of PD with age across regions (2), where the prevalence is predicted to double by the year 2030 (3). The economic burden of countries based on those contracted with PD will continue to rise as well. Estimated direct cost of PD in Europe in 2005 was $€ 10.7$ billion per year (4), while current estimates for the United States mention that combined direct and indirect costs of PD are $\$ 25$ billion per year (5). The economic cost increases as PD progresses $(6,7)$, and the medical care costs are the principal cost burden of $\mathrm{PD}$ patients $(6,7)$. On a comparative basis, the prevalence is significantly higher in North America, Europe, and Australia than in Asia, and males seem to be more susceptible than females (2).

The main characteristic of PD is a progressive loss of dopaminergic neurons resulting in the loss of motor function, non-motor symptoms, and cognitive decline $(1,3,8)$. The 3 major symptoms of PD are tremor, rigidity and bradykinesia $(1,5,8)$. Changes in taste and smell perception, clinical depression, gastro-intestinal dysfunction and sleep disturbance are the most important non-motor 
symptoms (5), and for some, early symptoms of PD appear long before the onset of the disease (9). The exact etiology of the disease is still unknown $(1,10,11)$. Around $10 \%$ of PD cases are found to be triggered by mutations in the alpha-synuclein, leucine-rich repeat kinase 2, Parkin, PINK, LRRK2 and several other genes $(10,11)$. As for the remaining $90 \%$ of PD cases which are sporadic (8), the combined effect of environmental exposure and genetic susceptibilities are believed to play a central role in the disease progression $(8,11)$. Along with aging, exposure to various environmental pollutants (especially pesticides), lack of sleep, obesity and a diet low in antioxidants are most extensively discussed as associated causes of $\operatorname{PD}(8,12)$.

Similar to many other chronic diseases for which no cure exists and with high economic burden on both the individuals and the society, complementary and alternative therapies (CAT) are a very popular method of combating PD. Some of the CAT include physical activity (especially Yoga and Tai chi), traditional herbs, dietary supplements, acupuncture and molecular targeted therapies $(13,14)$. Between 25.7 and $76 \%$ PD patients reach out to CAT with the aim of improving the associated motor symptoms. However, it is interesting to note that CAT is even recommended by health professionals up to $20 \%$ of times during patient consultations $(15,16)$.

The aim of this short review is to summarize the existing evidence on some selected plants used in traditional medicine for the treatment of PD. The paper focuses on plants from Europe and Asia which have been used for treating neurodegenerative diseases as a whole, as well as been extensively and holistically used around the globe, both as medical remedies or functional foods (i.e. bioactive components in various functional foods). Although many recent reviews elaborate the antioxidant potential of various plant-derived bioactive compounds for the treatment of PD, the pathology of the disease itself is complex and not fully elucidated, and it is doubtful whether the antioxidant potential of plants would be the sole mechanism of action which would combat the disease progression. Thus, in view of this lack of evidence to put the sole responsibility on oxidative stress as the root cause of $\mathrm{PD}$, we explored other potential anti-parkinsonian mechanisms of the selected plants in this review and their bioactive compounds responsible for these pathways.

\section{SEARCH STRATEGY AND SELECTION CRITERIA}

The focus of our paper were plants used for the treatment of $\mathrm{PD}$, and only plants tested in humans. As noted previously, plants with mechanisms of action beyond simply demonstrating antioxidant activities were selected.

The methodology for systematic reviews was modified and divided into a two stage process owing to the availability of references and the languages in which they are written. For the European plants, due to the lack of systematic databases on herbs traditionally used to treat $\mathrm{PD}$, the first stage focused on hard-cover books published in Croatia and surrounding countries (ex-Yugoslavia) to prepare the list of herbs used in Europe, and the oldest book used was Gursky (17). For herbs used in Asia, the same strategy was used, although the unavailability of books published in English was a challenge. Most of the books which were referred for this review were published in either Sinhala or Tamil, which are two native languages of Sri Lanka. Nevertheless, in order to avoid translational errors and misinterpretations, occasional referencing of Sinhala and Tamil books for verification purposes was carried out while primary sourcing was done in books published in English.

The list of plants retrieved from literature was then selected on the basis of the highest number of citations, which were then used for the second stage of the review. A search was conducted in the following databases: HRCAK (Croatian database), Pub Med, Cochrane, Medline Plus, ScienceDirect, Web of Science and Google Scholar. The following key words were used as the search terms: Ayurveda, Asparagus racemosus, Atropa belladonna, Gingko biloba, Hyoscyamus niger, Lepidium meyenii, Mucuna pruriens, Europe, Asia, herbs, herbal remedies, traditional medicine, Parkinson disease, neurodegenerative disease. The last search was conducted on July 18, 2018. Additionally, we searched the largest database of clinical trials (ClinicalTrials.gov) to identify whether any randomized clinical trial fits within the criteria. The last search was conducted on June 29, 2018 but out of three trials, none fit the criteria. Table 1 provides a summary of the plants, the part of the plant used for the treatment, their bioactive compounds, anti-neurodegenerative effects and other neuroprotective effects.

\section{EUROPEAN PLANTS}

Atropa belladona and Hyoscyamus niger are better known for their poisonous and narcotic effects than as treatments for neurodegenerative diseases. One murder case using $H$. niger in 1910 is even considered as ground-breaking in the science of forensic medicine in the UK (16). In Central European countries however, A. belladona and $H$. niger are listed as plants which can be used to treat $\mathrm{PD}$ and other forms of neurodegenerative diseases (i.e., Alzheimer's disease and dementia), but with extreme caution and under professional supervision (17). A. belladona and $H$. niger share bioactive components that show beneficial effects on PD, some of which are atropine, hyocyamine and scopolamine (18). These are even used as active components in some drugs for PD available on the market (18). The chemical structures of these compounds are shown in Figure 1A. Traditionally, powder prepared from A. belladona without the root, and tincture prepared from $H$. niger leaves are used to alleviate the motor symptoms of PD (17). Besides the direct anti-parkinsonian, anti-Alzheimer and anti-dementia effects, both plants contain bioactive components with other neuroprotective effects (Table 1). However, the lack of clinical evidence in the area of PD and other neurodegenerative diseases is substantial.

\section{Atropa belladonna L. (Solanaceae; Common Name: Nightshade)}

Europe, Asia and North Africa are considered the natural origins of A. belladona, with the exceptions of England and Scotland 
TABLE 1 | Bioactive compounds with neuroprotective effects isolated from European and Asian plants.

\begin{tabular}{|c|c|c|c|c|}
\hline Plant & $\begin{array}{l}\text { Plant } \\
\text { part }\end{array}$ & Bioactive compound & $\begin{array}{l}\text { Anti-neurodegenerative } \\
\text { effects }\end{array}$ & Other neuroprotective effects \\
\hline \multicolumn{5}{|l|}{ European } \\
\hline & & Atropine & Antiparkinsonian & Vasodilatator, CNS depressant and stimulant, anticholinergic \\
\hline & & Choline & $\begin{array}{l}\text { Antialzheimerman (6-16 } \\
\text { g/person/day), antidementia }\end{array}$ & Cholinergic, hypotensive, memorigenic, cerebrotonic \\
\hline & & Homatropine & & Anticholinergic, antiganglionic \\
\hline & & Hyoscyamine & Antiparkinsonian & CNS depressant and stimulant, anticholinergic, antineuralgic \\
\hline & & Phytosterols & & Hypocholesterolemic \\
\hline & & Pyridine & & CNS depressant \\
\hline & & Scopolamine & Antiparkinsonian & $\begin{array}{l}\text { CNS depressant, anticholinergic, anticonvulsant, } \\
\text { antiinflammatory }\end{array}$ \\
\hline & & Umbelliferone & & Anti-inflammatory \\
\hline \multirow[t]{9}{*}{$\begin{array}{l}\text { Hyoscyamus } \\
\text { niger }\end{array}$} & Plant & Choline & $\begin{array}{l}\text { Antialzheimeran 5-16 } \\
\text { g/person/day, antidementia, } \\
\text { memorigenic }\end{array}$ & Hypotensive, cerebrotonic, cholinergic \\
\hline & & Coumarin & & Anti-inflammatory \\
\hline & & Esculetin & & Anti-inflammatory \\
\hline & Leaf & Atropine & Antiparkinsonian & Anticholinergic, CNS depressant and stimulant \\
\hline & & Chlorogenic-acid & & Antioxidant, anti-inflammatory \\
\hline & & Gaba & & $\begin{array}{l}\text { Hypotensive 1,000-4,000 mg/day, CNS inhibitor, } \\
\text { anticonvulsant }\end{array}$ \\
\hline & & Hyoscyamine & Antiparkinsonian & $\begin{array}{l}\text { Anticholinergic } 150-300 \text { ug } 4 \times / \text { day/person, antineuralgic, } \\
\text { CNS depressant and stimulant }\end{array}$ \\
\hline & & $\begin{array}{l}\text { Fatty acids (myristic, oleic, } \\
\text { palmitic, stearic) }\end{array}$ & & Antioxidant, anti-inflammatory (oleic) \\
\hline & & Scopolamine & Antiparkinsonian & $\begin{array}{l}\text { Anticholinergic, CNS depressant, anticonvulsant, } \\
\text { anti-inflammatory }\end{array}$ \\
\hline \multirow[t]{6}{*}{$\begin{array}{l}\text { Lepidium } \\
\text { meyenii }\end{array}$} & Root & $\begin{array}{l}\text { Aminoacids (alanine, } \\
\text { arginine, glutamic acid, } \\
\text { glycine, histidine, leucine, } \\
\text { lysine, methionine, } \\
\text { phenylalanine, serine, } \\
\text { threonine, tryptophan, } \\
\text { tyrosine, valine) }\end{array}$ & $\begin{array}{l}\text { Antiparkinsonian } 1-5 \mathrm{~g} / \text { day } \\
\text { Methionine, } 200-500 \\
\mathrm{mg} / \text { day/man Phenylalanine, } 2 \mathrm{~g} \\
3 \mathrm{x} / \text { day Tryptophan, } 100 \\
\mathrm{mg} / \mathrm{kg} / \text { day Tyrosine, } \\
\text { antidementia } 3 \mathrm{~g} \text { Tryptophan/day }\end{array}$ & $\begin{array}{l}\text { Antihipertensive (Arginine), Vasodilatator (Arginine), } \\
\text { Hypotensive ( } 3 \mathrm{~g} \text { Tryptophan/day), Antidepressant } \\
\text { (50-4,000 mg Phenylalanine/day/person; } 1-3 \mathrm{~g} \text { Tryptophan } \\
3 \mathrm{x} \text { day/person orl, Tyrosine), Serotoninergic } 6-12 \mathrm{~g} \\
\text { Tryptophan/day/or//person }\end{array}$ \\
\hline & & Beta-sitosterol & & $\begin{array}{l}\text { Antihyperlipoproteinaemic, anti-inflammatory, } \\
\text { hypocholesterolemic ( } 2-6 \mathrm{~g} / \text { person/day orl) }\end{array}$ \\
\hline & & Campesterol & & Hypocholesterolemic \\
\hline & & Phytosterols & & $\begin{array}{l}\text { Hypocholesterolemic, antidepressant, hypotensive, } \\
\text { vasodilatator }\end{array}$ \\
\hline & & Stigmasterol & & Anti-inflammatory, antioxidant, hypocholesterolemic \\
\hline & & Tannin & & Antihypertensive \\
\hline
\end{tabular}


TABLE 1 | Continued

\begin{tabular}{|c|c|c|c|c|}
\hline Plant & $\begin{array}{l}\text { Plant } \\
\text { part }\end{array}$ & Bioactive compound & $\begin{array}{l}\text { Anti-neurodegenerative } \\
\text { effects }\end{array}$ & Other neuroprotective effects \\
\hline & & $\begin{array}{l}\text { Vitamins (ascorbic acid, } \\
\text { niacin, thiamin, riboflavin, } \\
\text { B12) }\end{array}$ & $\begin{array}{l}\text { Antiparkinsonian (1 g 2-3x/day } \\
\text { vitamin C, } 100 \text { mg/day niacin), } \\
\text { antialzheimerman (niacin, } \\
\text { 2,000-6,000 mg vit C/day, } \\
\text { 100-3,000 mg/day thiamin), } \\
\text { antidementia (vitamin C, niacin, } \\
\text { thiamin) }\end{array}$ & $\begin{array}{l}\text { Anticonvulsant (niacin } 3 \mathrm{~g} / \text { day), vasodilatator (vitamin C, } \\
\text { niacin), hypotensive (vit C 1,000 mg/person/day), } \\
\text { hypocholesterolemic (vit C 300-1,000 mg/day; } 50-100 \mathrm{mg} \\
\text { niacin 3x/day), antihypertensive (vitamin C), anti-inflammatory } \\
\text { (vitamin C), antineuralgic (niacin, } 1-4 \mathrm{~g} \text { thiamin/day), } \\
\text { antidepressant 2,000 mg vit C/day; serotoninergic (niacin) }\end{array}$ \\
\hline
\end{tabular}

\section{Asian}

Asparagu

racemosus
Root

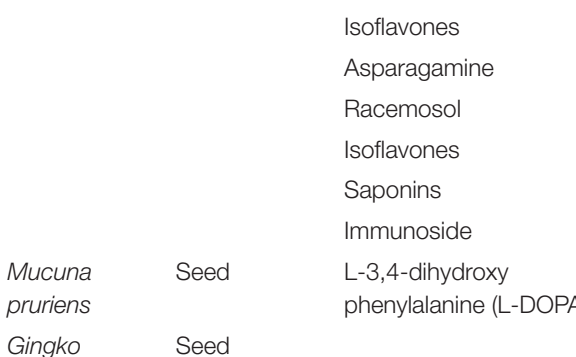

biloba

\section{Steroidal saponins Antiparkinsonioan \\ Steroidal saponins}

Anti-Alzheimers

Immunostimulatory

Anti-apoptotic

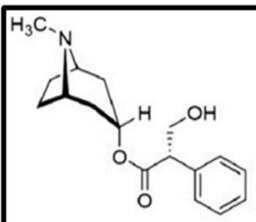

(-)-hyoscyamine

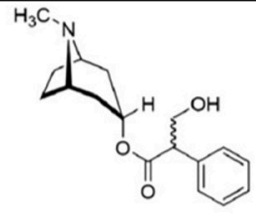

atropine (+)-)-hyoscyamine

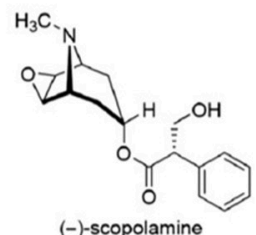

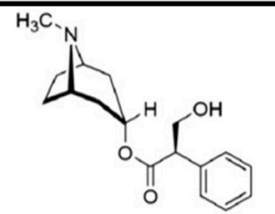

(+)-hyoscyamine

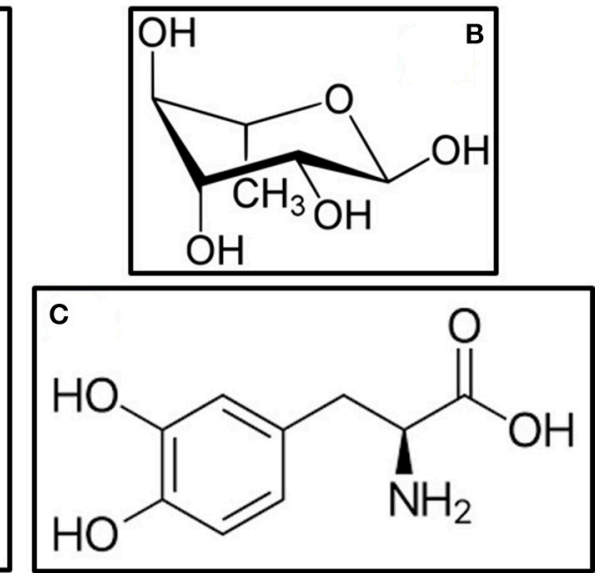

FIGURE 1 | Bioactive compounds present in (A) A. belladona and H. niger (18) (B) A. racemosus - Rhamnose (19), and (C) Mucuna pruriens - L-DOPA (20).

$(21,22)$. It prefers limestone or chalk grounds, hidden from direct exposure to sunlight (23). The stem is erect, purplish colored, and the root is over $15 \mathrm{~cm}$ long, thick and well developed (24). The flower has a campanulate-shaped corolla with five purplish to yellowish-purple painted hanging petals which become lighter in the downward direction. The maturity is reached in the second year with blooms from June maturing in early September, producing the black shiny berry fruits. All parts of the plant, including the kidney-shaped seeds are toxic (23).

Traditionally, A. belladona has been used in many cultures around the world as narcotic, anodyne (painkiller), antispasmodic, anticholinergic and diuretic effects, as well as for the treatment of rheumatism, fever, night sweeting, epilepsy, various cancers and mydriasis (dilated pupils) (18). Although poisonous, A. belladonna can act as an antidote in case of intoxication with morphine, pilocarpine and muscarine (17). Current medicine is well familiar with A. belladonna-based drugs. Atropine, scopolamine, anisodine and anisodamine inhibit the stimulant actions of acetylcholine $(\mathrm{ACh})$ on three levels. In the central nervous system (CNS), they inhibit the muscarinic cholinergic receptors, and inhibit ACh in peripheral structures innervated by the cholinergic nerves and smooth muscles responding to $\mathrm{ACh}$, but without cholinergic innervation (25-27). In large doses, these drugs cause learning and memory deficits, with scopalamine being the most potent (26). 


\section{Hyoscyamus niger L. (Solanaceae; Common Name: Black henbane, Henbane)}

Natural habitats of $H$. niger are Scandinavia and the northern part of Europe from where it has spread out worldwide such as to North America, Asia and North Africa $(28,29)$. It is considered as a highly adaptable and invasive species due to high tolerability of temperature and humidity ranges (30). $H$. niger is a vascular plant with great biodiversity and intense fragrance (31). The stem is $30-100 \mathrm{~cm}$, long, unbranched or rarely branched, covered with sticky hairs. It flowers between June and September, and flowers are of pale yellow color with visible purple veins. The fruit is a capsule that opens after maturity, immediately spreading black seeds following ripening (29). All plant parts are poisonous.

Every traditional medicine lists $H$. niger as a medicinal plant. Yet, the most common application is for pain treatment and as a narcotic, nevertheless, with a high frequency of intoxication especially among children (32). H. niger has anticolinergic, antisecretory and bronchodilating, spasmolytic, urinary bladder relaxant, hypnotic, hallucinogenic, pupil dilating, sedative, anti-diarrheal, anti-inflammatory, hypotensive, antimicrobial, anticolvunsant, and anticancerogenic effects $(18,33)$. It has been used to treat PD in Ayurveda as well, although as a minor component of herbal formulations (33). Similar to $A$. belladonna, atropine from $H$. niger is an effective antimuscarinic agent used for the treatment of intoxication with organophosphate compounds (33). In terms of PD treatment, potential mechanisms include lower monoamine oxidase (MAO) activity and protection of neuronal mitochondria from intestinal hydroxyl radical accumulation (34).

\section{Lepidium meyenii (Brassicaceae; Common Name: Maca, Peruvian Ginseng)}

The origin of $L$. meyenii is South America, primarily Peru highlands, at altitudes from 4,000 to $4,500 \mathrm{~m}$ above sea level (34). The tuberous root of L. meyenii is the edible part of the plant, with colors ranging from yellow, to red or extremely black (35). It can successfully tolerate wide temperature ranges from $-20^{\circ}$ to $20^{\circ} \mathrm{C}$, high exposure to sunlight and strong winds (36). Depending on the water content and temperatures, L. meyenii has the properties of an annual or biennial species (32).

In L. meyenii, the neuropotent compounds (Table 1) include amino acids and vitamins which are highly abundant in the root (18). While L. meyenii is mainly used as a supplement, native Peruvian population in the central Andes use the hypocotyls as food in an approximate amount of $>20 \mathrm{~g} / \mathrm{d}$ (37). Different varieties of $L$. meyenii, which can be recognized by the color of the hypocotyls, have different biological properties $(36,38)$. Traditionally, dried L. meyenii is commonly boiled or extracted in alcohol before consumption, and the method of preparation influences the content and composition of bioactive compounds $(36,38)$.

The most common traditional applications of $L$. meyenii as confirmed by clinical trials, are for sexual dysfunction, increased sperm count and motility $(36,39,40)$, as well as for the treatment of osteoporosis. L. meyenii reduces the number of fractures, regulates glucose and lipid metabolism while consequently reducing blood pressure, and protects the skin against ultraviolet radiation. The red variety of $L$. meyenii has been shown to reverse benign prostatic hyperplasia (35). Though traditionally, L. meyenii is not listed as a remedy for learning and memory enhancement, native Peruvians recommend its use in children to improve cognition but without specifying which variety of $L$. meyenii should be used (36). Black $L$. meyenii nevertheless, continuously shows the best results for memory and learning $(35,36,39)$. Antioxidant and acetylcholinesterase (AChE) inhibiting activities are the probable reason for black L. meyenii's potential in improving memory (41). On the other hand, antidepressant activity has been found in three varieties of L. meyenii: yellow, red and black (42). These activities were confirmed in animal models. The same team of researchers (41) then administered two concentrations of aqueous ( 0.50 and 2.00 $\mathrm{g} / \mathrm{kg})$ and hydroalcoholic $(0.25$ and $1.00 \mathrm{~g} / \mathrm{kg})$ extracts of black L. meyenii for 35 days to male mice with scopolamine-induced memory impairment. Both extracts significantly alleviated the scopolamine-induced memory impairment through inhibition of brain AChE activity, but without any effect on MAO activity (41). Recently, L. meyenii extract was also found to inhibit butyrylcholinesterase (BuChE) activity (43). Interestingly, the polyphenolic composition of the hydroalcoholic extract of black L. meyenii was mentioned as the probable reason for significant improvement of memory impairment induced by ethanol in mice, with a dose-response effect (42). In humans, $L$. meyenii reduces symptoms of depression and anxiety in males, but also reduces psychological symptoms including anxiety and depression in postmenopausal women during a six-week application in amounts of $3.5 \mathrm{~g} /$ day (35).

\section{ASIAN PLANTS}

The Asian plants selected for the review are collectively used in traditional Ayurvedic medicinal systems, primarily in the Indian sub-continent. While many similarities in the bioactive compounds were present in the European herbs, the Asian herbs have not shown such significant overlapping chemical compositions, although L-3,4-dihydroxy phenylalanine (L-DOPA) has been found in both M. pruriens and G. biloba. This demonstrates the diversity of compounds which can be used for anti-PD effects and the potential to eventually develop medical remedies using herbal combinations for better overall therapeutic outcomes in preventing the disease progression.

\section{Aspargus racemosus (Asparagaceae)}

Known as Satawar, Satamuli, Satavari, of A. racemosus is a woody, perennial climber, a spinous under-shrub reaching a height above 1-2 $\mathrm{m}$. The name Shatavari is an Indian word, meaning "women who have 100 husbands" suggesting its effects on fertility and viability. It is indigenous to India, Sri Lanka and the Himalayas where it can be found at altitudes of 1,300-1,400 m, while the plant is found in Australia, other parts of Asia and Africa in lowshaded altitudes (44). The plant grows well on different soil types from light, sandy to heavy (clay) or rocky, under hot climates with minimum rainfall $(45,46)$. The upper part of the plant has needle-like leaves, while the flowers are white and scented, and 
the fruit is a red-colored berry with one seed $(47,48)$. The root is tuberous, with numerous tubers of lengths of $30-100 \mathrm{~cm}$. The plant blooms during February-March and ripens in April $(49,50)$.

Almost all parts of $A$. racemosus are used in many of the South Asian traditional medicinal systems for the treatment of various ailments in human beings (51). Classical treatment of using A. racemosus include powdering the root (Table 1 ) and taking in $12 \mathrm{~g}$ dosages with $100-250 \mathrm{~mL}$ milk twice a day (49). It belongs to the "rasayana" class of herbs which enhance physical and mental health, improve the immune response, and enhance longevity (50). A. racemosus showed high free radical scavenging as well as neurotropic modulatory properties in diseases associated with neuron cell loss $(51,52)$. Administration of the methanolic root extract of $A$. racemosus prevented scopolamine- and sodium nitrite-induced amnesia showing a great potential in memory deficits (53). The anti-PD compounds present in A. racemosus include racemosol and rhamnose (19). The chemical structure of rhamnose is shown in Figure 1B. In the study by Jayashree et al. (54), LC-ESI-MS/MS analysis of the methanolic extract of the root of this plant showed the presence of flavonoids, saponins and shatavarins. In this study, the effect of A. racemosus extract was assessed in the prevention of tert-Butyl hydroperoxide ( $t$ BHP)-induced damage in Wistar rats. The rats were treated with $1 \mathrm{mmol} / \mathrm{kg}$ body weight of t-BHP to induce oxidative stress. Supplementation with $A$. racemosus decreased the level of lipid peroxidation products after $\mathrm{t}-\mathrm{BHP}$ treatment. A. racemosus is used to treat rigidity of limbs and is a memory stimulant (55). The root extract has been observed to contain immunoside, which is a sarsasapogenin glycoside used for immunostimulatory activities (56). Bhatnagar et al. (57) investigated the effect of the aqueous root extract of $A$. racemosus in primary hippocampal neuron cell culture. The extract was shown to be potent when combined with Withania somnifera to induce neuroprotection in this particular study (58).

\section{Mucuna pruriens L. (Fabaceae)}

Also known as velvet bean, cowitch, Bengal velvet bean, cowage, lacuna bean and Lyon bean (English common names), $M$. pruriens is an annual, self-pollinated legume originating from South China, Malaysia and eastern India from where it has spread worldwide and is cultivated as a green vegetable crop $(59,60)$. According to Padmesh et al. (60), this species has at least three varieties in India; $M$. pruriens (L.) DC, M. pruriens (L.) DC var. pruriens and M. pruriens var. utilis (Wall ex Wight) Baker ex Burck. This is an invasive species, and like other Legume species, it is also known as a weed controller (61). The stem is thin and long and a climber with aggregated flowers which are white in color. The fructus pod has long silky hairs containing 4-6 seeds and the chemical mucunain that causes itchy dermatitis $(62,63)$. For the full development, the plant requires wet, warm conditions, and flowers between August and April while the pod matures between October and January (30).

Many researchers have found that $M$. pruriens contains LDOPA, which provides long-term amelioration of PD (63-65). $M$. pruriens had also shown positive effects on $\mathrm{PD}$ patients in clinical trials, with a quick onset of action and without concomitant increase in dyskinesia $(63,66)$. Additionally,
Zandopa (HP-200) - a commercial preparation of $M$. pruriens is also available for the treatment of $\operatorname{PD}(63,67)$. In a study by Yadav et al. (68), the neuroprotective effects of an ethanolic extract of M. pruriens seeds (Table 1) were evaluated in a Parkinsonian mice model where symptoms were induced by the pesticide paraquat. It was observed that the extract improved the motor abnormalities observed in PD mice, as well as effectively rescued the levels of dopamine and its metabolites in substantia nigra. Furthermore, Yadav et al. (69) evaluated the therapeutic effects of the aqueous extract of $M$. pruriens seed in PD mouse model developed by chronic exposure to paraquat. In this study, it was revealed that the nigrostriatal portion of $\mathrm{PD}$ mouse brain showed significantly increased levels of nitrite, malondialdehyde (MDA) and reduced levels of catalase compared with controls. In the study by Poddighe et al. (20), a PTEN-induced putative kinase 1 mutant of Drosophila melanogaster were treated with the methanolic extract of $M$. pruriens. Their results showed multiple centers of action, indicating that its effectiveness goes well beyond its L-DOPA content (70). The chemical structure of L-DOPA is shown in Figure 1C. Also, the extract was found to be able to delay the onset of chronic L-DOPA-induced long-term motor complications. As additional treatments extending from this plant, $M$. pruriens can relieve inflammation, neuropathy, nephropathy, delirium, cephalagia, general debility, dysmenorrhea, amenorrhoea, ulcers, constipation, elephantiasis, consumption, helminthiasis, fever and dropsy (70).

\section{Ginkgo biloba (Ginkgoaceae)}

Ginkgo biloba is a long-living tree, which can live up to thousand years or more reaching over $30 \mathrm{~m}$ in height. The name Ginkgo comes in several name variations such Yajiao (meaning duck foot), Bajguo (white nut), Gongsunshu (grandfather/grandson tree), Icho or Yinxing (silver apricot) or maidenhair tree (71). Eastern China, Zhejiang region, are natural habitats (72). Ginkgo has over 200 cultivars that differ from native species in size, shape and color of the leaves (72).

Ginkgo biloba has a special place in Traditional Chinese Medicine as one of the most widely cultured plants; it has antioxidant and free radical scavenger properties $(73,74)$ which are associated with its neuroprotective/ anti-apoptotic activity (75) (Table 1). Biological activities of the standardized extract of $G$. biloba $\left(\mathrm{EGb} \mathrm{1}^{\circledR}\right.$ ) have been researched for more than 20 years (76). Nevertheless, given the vast amount of research which is currently available and the extensive usage of this herb in neuroprotective effects, this portion of the review focused only on a few studies which have stood out as updates on the therapeutic properties of the herb.

Recently, Gu et al. (77) evaluated the G. biloba's therapeutic role toward ischemia/ reperfusion (I/R) injury through determination of monoamine neurotransmitter dopamine in corpus striatum in male Sprague-Drawley rats. The mechanism of action is through prevention of excessive release of dopamine in striatum. Wang and Wang (78) observed that it attenuates oxidative stress and apoptosis in mouse cochlear neural stem cells. The extract of this herb is known to contain flavonoids which slow down the oxygen consumption of the stimulated 
cells by its inhibitory action on NADPH oxidase $(79,80)$. Amentoflavone has been observed as one of the primary bioactive compounds present in G. biloba against PD (81). This compound has shown activity at the allosteric benzodiazepine site of the $\gamma$-aminobutyric acid-A receptor $\left(\mathrm{GABA}_{\mathrm{A}}\right)$ as a negative allosteric modulator. Polyphenols from G. biloba, consisting of namely quercetin and kaemferol, have been shown to have antidepressant-like effects in mice and increased neuronal survival and plasticity through allosteric modulation as well $(82,83)$. According to Hang et al. $(84)$, EGb761 ${ }^{\circledR}$ prevents the formation of apoptosome and the apoptotic cascade by blocking cytochrome-c release.

\section{CONCLUSIONS AND FUTURE DIRECTIONS}

With the growing elderly population around the globe, it is not surprising that healthy aging has become one of the top priorities, with $\mathrm{PD}$ at the center of attention. There are many commercial drugs available in the market. However, their inadequacy has led to the search for novel treatments for PD. In view of this flaw, this review highlights the importance of an urgent need to initiate remedial action toward neurological disorders such as PD, at least through CAT. A recent systematic review of randomized controlled trials by Kim et al. (85) did not adequately summarize the evidence on the effectiveness of herbal medicines for PD due to the large heterogeneity between herbal mixtures being used for this disorder as well as the nature of the study designs. Still,

\section{REFERENCES}

1. Tysnes OB, Storstein A. Epidemiology of Parkinson's disease. J Neural Transm. (2017) 124:901-5. doi: 10.1007/s00702-017-1686-y

2. Pringsheim T, Jette N, Frolkis A, Steeves TD. The prevalence of Parkinson's disease: a systematic review and meta-analysis. Mov Disord. (2014) 29:158390. doi: $10.1002 / \mathrm{mds} .25945$

3. Tan LSC. Epidemiology of Parkinson's disease. Neurol Asia (2013) 18:231-8. Available online at: https://www.neurology-asia.org/articles/neuroasia-201318(3)-231.pdf

4. Dodel R. Interpreting health economics data in Parkinson's disease. Eur Neurol Rev. (2011) 6(Suppl. 1):13-6. Available online at: https://www. touchneurology.com/system/files/private/articles/9012/pdf/dodel.pdf

5. Gaba A. Recent studies on nutrition and Parkinson's disease prevention: a systematic review. Open J Prev Med. (2015) 5:197-205. doi: 10.4236/ojpm.2015.55023

6. Findley LJ, Wood E, Lowin J, Roeder C, Bergman A, Schifflers M. The economic burden of advanced Parkinson's disease: an analysis of a UK patient dataset. J Med Econ. (2011) 14:130-9. doi: 10.3111/13696998.2010.551164

7. Mateus C, Coloma J. Health economics and cost of illness in Parkinson's disease. Eur Neurol Rev. (2013) 8:6-9. doi: 10.17925/ENR.2013.08.01.6

8. Agim ZS, Cannon JR. Dietary factors in the etiology of Parkinson's disease. BioMed Res Int. (2015) 2015:672838. doi: 10.1155/2015/672838

9. Rodríguez-Violante M, Zerón-Martínez R, Cervantes-Arriaga A, Corona T. Who can diagnose Parkinson's disease first? Role of pre-motor symptoms. Arch Med Res (2017) 48:221-7. doi: 10.1016/j.arcmed.2017.08.005

10. Pavlou MAS, Outeiro TF. Epigenetics in Parkinson's disease. Adv Exp Med Biol. (2017) 978:363-90. doi: 10.1007/978-3-319-53889-1_19

11. Fleming SM. Mechanisms of gene-environment interactions in Parkinson's disease. Curr Environ Health Rep (2017) 4:192-9. doi: 10.1007/s40572-017-0143-2 the interest in PD is growing, and current experimental evidence does suggest that a number of plants show some neuroprotective potential, well beyond simply demonstrating antioxidant activity. Along with the bioactive compounds described herein, those described by Fu et al. (86), as well as components isolated from Curcuma longa $(87)$ and Panax ginseng $(88,89)$ will continue to be in the focus of interest for the development of alternative PD treatments.

Out of plants described here, A. racemosus is the most interesting of all because of its great potential to be developed into a herbal remedy and also because it is consumed as a functional food. On the other hand, herbs such as G. biloba $\left(\right.$ EGb761 $\left.{ }^{\circledR}\right)$ have already been commercialized as a potential remedy for neurodegenerative diseases. As highlighted in this review as well as by Campos et al. (90), along with potent neuroprotective effects, (91) many plant bioactive compounds offer diversity which is needed for the holistic recovery from neurodegenerative diseases. More systematic studies are required to elucidate the effectiveness of these plants, including isolation of novel compounds with therapeutic potential. Through such efforts, the burden of the disease upon patients and economies alike could be reduced for the purpose of health and well-being.

\section{AUTHOR CONTRIBUTIONS}

IB, TM, ST, and VW equally contributed to the acquisition of information, drafting the manuscript and approving the final version.

12. Navarro-Meza M, Gabriel-Ortiz G, Pacheco-Moisés FP, Cruz-Ramos JA, López-Espinoza A. Dietary fat and antioxidant vitamin intake in patients of neurodegenerative disease in a rural region of Jalisco, Mexico. Nutr Neurosci. (2014) 17:260-7. doi: 10.1179/1476830513Y.0000000089

13. Dong J, Cui Y, Li S, Le W. Current pharmaceutical treatments and alternative therapies of Parkinson's disease. Curr Neuropharmacol. (2016) 14:339-55. doi: 10.2174/1570159X14666151120123025

14. Bega D, Zadikoff C. Complementary \& alternative management of Parkinson's disease: An evidence-based review of eastern influenced practices. J Mov Disord. (2014) 7:57-66. doi: 10.14802/jmd.14009

15. Wang Y, Xie CL, Wang WW, Lu L, Fu DL, Wang XT, et al. Epidemiology of complementary and alternative medicine use in patients with Parkinson's disease. J Clin Neurosci. (2013) 20:1062-7. doi: 10.1016/j.jocn.2012.10.022

16. Lee MR. Solanaceae III: henbane, hags and Hawley Harvey Crippen. J R Coll Phys Edinburgh (2006) 36:366-73.

17. Gursky Z. Zlatna Knjiga Ljekovitog Bilja [in Croatian]. Zagreb: Nakladni zavod Matice Hrvatske (1978).

18. National Agricultural Library. Dr. Duke's Phytochemical and Ethnobotanical Databases (2017). Available online at: https://phytochem.nal.usda.gov/ phytochem/search (Accessed April 6, 2018).

19. Bagchi P, Anuradha M, Kar A. Ayur-Informatics: establishing an Ayurvedic medication for Parkinson's disorder. Int J Adv Chem Eng Biol Sci. (2017) 4:21-25. doi: 10.15242/IJACEBS.EAP117202

20. Poddighe S, De Rose F, Marotta R, Ruffilli R, Fanti M, Secci PP, et al. Mucuna pruriens (Velvet bean) rescues motor, olfactory, mitochondrial and synaptic impairment in PINK1B9 Drosophila melanogaster genetic model of Parkinson's disease. PLoS ONE 9:e110802. doi: 10.1371/journal.pone.0110802

21. Euro+Med PlantBase. The Information Resource for Euro-Mediterranean Plant Diversity (2006). Available online at: http://ww2.bgbm.org/ EuroPlusMed/(Accessed March 29, 2018).

22. Butcher RW. Atropa belladonna L. J Ecol. (1947) 34:345-53. 
23. Paul R, Animesh DK. An updated overview on Atropa belladonna L. Int J Pharm. (2011) 2:11-17.

24. Lee MR. Solanaceae IV: Atropa belladonna, deadly nightshade. J R Coll Phys Edinburgh (2007) 37:77-84.

25. Pharmacopeial Convention Herbal Medicines Compendium. Atropa belladonna Leaf (2014). Available online at: https://hmc.usp.org/monographs/ atropa-belladonna-leaf-0-1(Accessed March 28, 2018).

26. Pan SY, Han YF. Comparison of the inhibitory efficacy of four Belladonna drugs on gastrointestinal movement and cognitive function in food-deprived mice. Pharmacology (2004) 72:177-83. doi: 10.1159/000080102

27. Scullion JE. The development of anticholinergics in the management of COPD. Int J Chron Obstruct Pulmon Dis. (2007) 2:33-40.

28. Mitich LW. Intriguing world of weeds: black henbane. Weed Technol. (1992) 6:489-91. doi: 10.1017/S0890037X00035120

29. Pudersell K. Tropane Alkaloid Production and Riboflavine Excretion in the Field and Tissue Cultures of Henbane (Hyoscyamus niger L.). Doctoral thesis. Faculty of Medicine, University of Tartu, Estonia (2006).

30. CABI. Invasive Species Compendium Available online at: https://www.cabi. org/isc/datasheet/35134\#C2314D67-7351-4C34-8A0F-DCDE86F2393B (Accessed April 9, 2018).

31. Panda H. Medicinal Plants Cultivation \& Their uses. New Delhi: Asia Pacific Buissnes Press Inc. (2002). 85-7.

32. Muhammad I, Zhao J, Khan IA. Maca (Lepidium meyenii). In: Coates MP, Blackman MR, Cragg GM, Levine M, Moss J, White JD. Marrcel D, editors. Encyclopedia of Dietary Supplements. New York, NY: CRC Press (2005). 45-65.

33. Alizadeh A, Moshiri M, Alizadeh J, Balali-Mood M. Black henbane and its toxicity - a descriptive review. Avicenna J Phytomed. (2014) 4:297-311.

34. Koppula S, Kumar H, More SV, Lim HW, Hong SM, Choi DK. Recent updates in redox regulation and free radical scavenging effects by herbal products in experimental models of Parkinson's disease. Molecules (2012) 17:11391-420. doi: 10.3390/molecules171011391

35. Gonzales GF, Villaorduña L, Gasco M, Rubio J, Gonzales C. Maca (Lepidium meyenii Walp), una revisión sobre sus propiedades biológicas. Revista Peruana de Medicina Experimental y Salud Pública (2014) 31:100-10.

36. Gonzales GF. Ethnobiology and ethnopharmacology of Lepidium meyenii (Maca), a plant from the Peruvian highlands. Evid Based Complement Alternat Med. (2012) 2012:193496. doi: 10.1155/2012/193496

37. Quirós CF, Epperson A, Hu J, Holle M. Physiological and cytological characterization of maca, Lepidium meyenii Walp. Econ Bot. (1996) 50:216-23.

38. Rubio J, Caldas M, Dávila S, Gasco M, Gonzales GF. Effect of three different cultivars of Lepidium meyenii (maca) on learning and depression in ovariectomized mice. BMC Complement Alternat Med. (2006) 6:23. doi: 10.1186/1472-6882-6-23

39. Gonzales GF, Gonzales C, Gonzales-Castañeda C. Lepidium meyenii (Maca): a plant from the highlands of Peru - from tradition to science. Forsch Komplementarmed. (2009) 16:373-80. doi: 10.1159/000264618

40. Gonzales GF, Gasco M, Cordova A, Chung A, Rubio J, Villegas L. Effect of Lepidium meyenii (Maca) on spermatogenesis in male rats acutely exposed to high altitude (4340 m). J Endocrinol (2004) 180:87-95. doi: 10.1677/joe.0.1800087

41. Rubio J, Dang H, Gong M, Liu X, Chen S-I, Gonzales GF. Aqueous and hydroalcoholic extracts of Black Maca (Lepidium meyenii) improve scopolamine-induced memory impairment in mice. Food and Chem Toxicol. (2007) 45:1882-90. doi: 10.1016/j.fct.2007.04.002

42. Rubio J, Yucra S, Gasco M, Gonzales GF. Dose-response effect of black maca (Lepidium meyenii) in mice with memory impairment induced by ethanol. Toxicol Mech Methods (2011) 21:628-34. doi: 10.3109/15376516.2011.583294

43. Zhou Y, Li P, Brantner A, Wang H, Shu X, Yang J, et al. Chemical profiling analysis of Maca using UHPLC-ESI-Orbitrap MS coupled with UHPLC-ESIQqQ MS and the neuroprotective study on its active ingredients. Sci Rep. (2017) 7:44660. doi: 10.1038/srep44660

44. Alok S, Jain SK, Verma A, Kumar M, Mahor A, Sabharwal M. Plant profile, phytochemistry and pharmacology of Asparagus racemosus (Shatavari): A review. Asian Pac J Trop Dis. (2013) 3:242-51. doi: 10.1016/S2222-1808(13)60049-3

45. Sharma PC, Yelne MB, Dennis TJ, Joshi A, Billore KV. Database on Medicinal Plants Used in Ayurveda. New Delhi: Central Council for Research in
Ayurveda \& Siddha; Department of ISM \& H; Ministry of Health and Family Welfare, Government of India (2000).

46. Sachan AK, Das DR, Dohare SL, Shuaib M. Asparagus racemosus (Shatavari): an overview. Int J Pharm Chem Sci. (2012) 1:937-41.

47. Sharma A, Sharma V. A brief review of medicinal properties of Asparagus racemosus (Shatawari). Int J Pure Appl Biosci. (2013) 1:48-52.

48. Govindarajan R, Vijayakumar M, Pushpangadan P. Antioxidant approach to disease management and the role of 'Rasayana' herbs of Ayurveda. $J$ Ethnopharmacol. (2005) 99:165-78. doi: 10.1016/j.jep.2005.02.035

49. Rout OP, Acharya R, Gupta R, Inchulkar SR, Karbhal KS, Sahoo R. Management of psychosomatic disorders through Ayurvedic drugs - A critical review. World J Pharm Pharm Sci. (2013) 2:6507-37.

50. Carradori S, D’Ascenzio M, Chimenti P, Secci D, Bolasco A. Selective MAOB inhibitors: a lesson from natural products. Mol Divers. (2014) 18:219-43. doi: 10.1007/s11030-013-9490-6

51. Goel S, Ojha NK. Astang Ghrita: a noble Ayurveda drug for central nervous system. J Ayurveda Holistic Med. (2015) 3:18-24. Available online at: http:// www.jahm.in/index.php/JAHM/article/view/312/pdf_123

52. Bhatnagar M, Meena P, Barbar S, Joshi C. Neuroprotective response of the hippocampus region of the brain to Withania somnifera and Asparagus racemosus root extract: an in vitro study. Afr. J Zool. (2010) 1:7-11.

53. Dhwaj AV. Reversal effect of Asparagus racemosus Wild (Liliaceae) root extract on memory deficits of mice. Int J Drug Dev Res. (2011) 3:314-23. Available online at: http://www.ijddr.in/drug-development/reversal-effectof-asparagus-racemosus-wildliliaceae-root-extract-on-memory-deficits- ofmice.php? aid $=5603$

54. Jayashree GV, Kumar KH, Krupashree K, Rachitha P, Khanum F. LC-ESIMS/MS analysis of Asparagus racemosus Willd. roots and its protective effects against t-BHP induced oxidative stress in rats. Ind Crops Prod. (2015) 78:1029. doi: 10.1016/j.indcrop.2015.10.024

55. Jacquet AR, Subedi R, Ghimire SK, Rochet JC. Nepalese traditional medicine and symptoms related to Parkinson's disease and other disorders: Patterns of the usage of plant resources along the Himalayan altitudinal range. $J$ Ethnopharmacol. (2014) 153:178-89. doi: 10.1016/j.jep.2014.02.016

56. Sidiq T, Khajuria A, Suden P, Singh S, Satti NK, Suri KA, et al. A novel sarsasapogenin glycoside from Asparagus racemosus elicits protective immune responses against HBsAg. Immunol Lett. (2011) 135:129-35. doi: 10.1016/j.imlet.2010.10.013

57. Bhatnagar M, Meena P, Barbar S, Joshi C. Neuroprotective response of the hippocampus region of the brain to Withania somnifera and Asparagus racemosus root extract: an in vitro study. J Med Plants Res. (2013) 7:2259-64. doi: 10.5897/JMPR12.497

58. Ceballos AIO, Rivera JRA, Arce MMO, Valdivia CP. Velvet bean (Mucuna pruriens var. utilis) a cover crop as bioherbicide to preserve the environmental services of soil. In: Alvarez-Fernandez R, editor. Herbicides Environmental Impact Studies and Management Approaches. Rijeka: INTECH (2012).

59. Musthafa, SM Asgari SM, Kurian A, Elumalai P, Ali ARJ, Paray BA, et al. Protective efficacy of Mucuna pruriens (L.) seed meal enriched diet on growth performance, innate immunity, and disease resistance in Oreochromis mossambicus against Aeromonas hydrophila. Fish Shellf Immunol. (2018) 75:374-80. doi: 10.1016/j.fsi.2018.02.031

60. Padmesh P, Reji JV, Dhar MJ, Seeni S (2006) Estimation of genetic diversity in varieties of Mucuna pruriens using RAPD. Biol Plantarum (2006) 50:367-72. doi: 10.1007/s10535-006-0051-z

61. Infante ME, Perz AM, Simao MR, Manda F, Baquete EF, Fernandes AM, et al. Outbreak of acute toxic psychois attributed to Mucuna pruriens. Lancet (1990) 336:1129. doi: 10.1016/0140-6736(90)92603-F

62. Lampariello LR, Cortelazzo A, Guerranti R, Sticozzi C, Valacchi G. The magic velvet bean of Mucuna pruriens. J Tradit Complement Med. (2012) 2:331-9. doi: 10.1016/S2225-4110(16)30119-5

63. More SV, Kumar H, Kang SM, Song SY, Lee K, Choi DK. Advances in neuroprotective ingredients of medicinal herbs by using cellular and animal models of Parkinson's disease. Evid-Based Complement Alternat Med (2013)0.2013:957875. doi: 10.1155/2013/957875

64. Lieu CA, Kunselman AR, Manyam BV, Venkiteswaran K, Subramanian T. A water extract of Mucuna pruriens provides long-term amelioration of 
parkinsonism with reduced risk for dyskinesias. Parkinsonism Relat Disord. (2010) 16:458-65. doi: 10.1016/j.parkreldis.2010.04.015

65. Manyam BV, Dhanasekaran M, Hare TA. Neuroprotective effects of the antiparkinson drug Mucuna pruriens. Phytother Res. (2004) 18:706-12. doi: $10.1002 / p t r .1514$

66. Katzenshlager R, Evans A, Manson A, Patsalos PN, Ratnaraj N, Watt H, et al. Mucuna pruriens in Parkinson's disease: a double blind clinical and pharmacological study. J Neurol Neurosurg Psychiatry (2004) 75:1672-7. doi: 10.1136/jnnp.2003.028761

67. Song JX, Sze SCW, Ng TB, Lee CK, Leung GP, Shaw PC, et al. Anti-Parkinsonian drug discovery from herbal medicines: What have we got from neurotoxicmodels? J Ethnopharmacol. (2012) 139:698-711. doi: 10.1016/j.jep.2011.12.030

68. Yadav SK, Rai SN, Singh SP. Mucuna pruriens shows neuroprotective effect by inhibiting apoptotic pathways of dopaminergic neurons in the paraquat mouse model of Parkinsonism. Eur J Pharm Medical Res. (2016) 3:44151. Available online at: http://www.ejpmr.com/admin/assets/article_issue/ 1469872643.pdf

69. Yadav SK, Prakash J, Chouhan S, Singh SP. Mucuna pruriens seed extract reduces oxidative stress in nigrostriatal tissue and improves neurobehavioral activity in paraquat-induced Parkinsonian mouse model. Neurochem Int. (2013) 62:1039-47. doi: 10.1016/j.neuint.2013.03.015

70. Sarrafchi A, Bahmani M, Shirzad H, Rafieian-Kopaei M. Oxidative stress and Parkinson's disease: new hopes in treatment with herbal antioxidants. Curr. Pharm Design (2016) 22:238-46. doi: 10.2174/1381612822666151112151653

71. Begović BM. Ginkgo biloba Nature’s Miracle, Book 1 Vol. 1-2). Croatia: Self-Publishing; Branko M Begovic Bego (2011).

72. Liang L. The contemporary ginkgo encyclopedia of China. Beijing Agric Univ. Press (1993).

73. Saki K, Bahmani M, Rafieian-Kopaei M. The effect of most important medicinal plants on two importnt psychiatric disorders (anxiety and depression) - A review. Asian Pac J Trop Med. (2014) 7:S34-42 doi: 10.1016/S1995-7645(14)60201-7

74. Alok S, Jain SK, Verma A, Kumar M, Mahor A, Sabharwal M. Herbal antioxidant in clinical practice: A review. Asia Pac J Trop Biomed. (2014) 4:78-84 doi: 10.1016/S2221-1691(14)60213-6

75. Jahanshahi M, Nickmahzar EG, Babakordi F. The effect of Ginkgo biloba extract on scopolamine-induced apoptosis in the hippocampus of rats. Anatom Sci Int. (2013) 88:217-22. doi: 10.1007/s12565-013-0188-8

76. El-Ghazaly MA, Sadik NAH, Rashed ER, Abd-El-Fattah AA. Neuroprotective effect of EGb761 ${ }^{\circledR}$ and low-dose whole-body $\gamma$-irradiation in a rat model of Parkinson's disease. Toxicol Ind Health (2013) 31:1128-43. doi: $10.1177 / 0748233713487251$

77. Gu J, He XR, Chen LP. The protective effect of Ginkgo biloba leaves injection on the brain dopamine in the rat model of cerebral ischemia/reperfusion injury. Afr Health Sci. (2014) 14:725-8. doi: 10.4314/ahs.v14i3.31

78. Wang CP, Wang B. Ginkgo biloba extract attenuates oxidative stress and apoptosis in mouse cochlear neural stem cells. Phytother Res (2016) 30:774-80. doi: $10.1002 /$ ptr.5572

79. Maraldi T. Natural compounds as modulators of NADPH oxidases. Oxidative Medicine and Cellular Longevity (2013) 2013:271602. doi: $10.1155 / 2013 / 271602$.
80. Lin FY, Chen YH, Chen YL, Wu T-C, Li C-Y, Chen J-W et al. Ginkgo biloba extract inhibits endotoxin-induced human aortic smooth muscle cell proliferation via suppression of toll-like receptor 4 expression and NADPH oxidase activation. J Agric Food Chem. (2007) 55:1977-84. doi: $10.1021 /$ jf062945r

81. Jeyam M, Karthika GRR, Poornima V, Sharanya M. Molecular understanding and in silico validation of traditional medicines for Parkinson's disease. Asian J Pharm Clin Res. (2012) 5:125-8.

82. Trebatická J, DuraIková Z. Psychiatric disorders and polyphenols: can they be helpful in therapy? Oxid Med Cell Longev. (2015) 2015:248529. doi: $10.1155 / 2015 / 248529$

83. Hou Y, Aboukhatwa MA, Lei DL, Manaye K, Khan I, Luo Y. Antidepressant natural flavonols modulate BDNF and beta amyloid in neurons and hippocampus of double TgAD mice. Neuropharmacology (2010) 58:91120. doi: 10.1016/j.neuropharm.2009.11.002

84. Hang LT, Basil AH, Lim KL. Nutraceuticals in Parkinson's disease. Neuromol Med. (2016) 18:306-21. doi: 10.1007/s12017-016-8398-6

85. Kim TH, Cho KH, Jung WS, Lee MS. Herbal medicines for Parkinson's disease: a systematic review of randomized controlled trials. PLoS ONE (2012) 7:e35695. doi: 10.1371/journal.pone.0035695

86. Fu W, Zhuang W, Zhou S, Wang X. Plant-derived neuroprotective agents in Parkinson's disease. Am J Transl Res. (2015) 7:1189-202.

87. Ma XW, Guo RY. Dose-dependent effect of Curcuma longa for the treatment of Parkinson's disease. Exp Ther Med. (2017) 13:1799-805. doi: 10.3892/etm.2017.4225

88. Cho IH. Effects of Panax ginseng in neurodegenerative diseases. J Ginseng Res. (2012) 36:342-53. doi: 10.5142/jgr.2012.36.4.342

89. González-Burgos E, Fernandez-Moriano C, Gómez-Serranillos MP. Potential neuroprotective activity of Ginseng in Parkinson's disease: a review. J Neuroimmune Pharm. (2015) 10:14-29. doi: 10.1007/s11481-0149569-6

90. Campos HC, da Rocha MD, Viegas FP, Nicastro PC, Fossaluzza PC, Fraga CA, et al. The role of natural products in the discovery of new drug candidates for the treatment of neurodegenerative disorders I: Parkinson's disease. CNS Neurol Disord Drug Targets (2011) 10:239-50. doi: $10.2174 / 187152711794480483$

91. Singla R, Jaitak V. Shatavari (Asparagus racemosus Wild): a review on its cultivation, morphology, phytochemistry and pharmacological importance. Int J Pharm Sci Res. (2014) 5:742-57. doi: 10.13040/IJPSR.0975-8232.5(3).742-57

Conflict of Interest Statement: The authors declare that the research was conducted in the absence of any commercial or financial relationships that could be construed as a potential conflict of interest.

Copyright (๑) 2018 Banjari, Marček, Tomić and Waisundara. This is an open-access article distributed under the terms of the Creative Commons Attribution License (CC $B Y)$. The use, distribution or reproduction in other forums is permitted, provided the original author(s) and the copyright owner(s) are credited and that the original publication in this journal is cited, in accordance with accepted academic practice. No use, distribution or reproduction is permitted which does not comply with these terms. 